\title{
Pengaruh Model Pembelajaran Visual-Auditory- Kinesthetic (Vak) Terhadap Kemampuan Berpikir Kritis Di Kelas Tinggi Sekolah Dasar
}

\author{
Wiwit Lathifah Febrilyani ${ }^{1}$, Andi Nurochmah ${ }^{2}$, Astri Sutisnawati ${ }^{3}$ \\ 1)23)Program Studi Pendidikan Guru Sekolah Dasar; FKIP Universitas \\ Muhammadiyah Sukabumi ; Jalan. R. Syamsudin, S. H. 50 Sukabumi; \\ Telpon. (0266) 218342, 218345; Faksimili (0266) \\ 218342;wiwitlf27@gmail.com
}

\begin{abstract}
Abstrak. Penelitian ini bertujuan untuk mengetahui pengaruh model pembelajaran VAK terhadap kemampuan berpikir kritis matematika pada materi bangun datar di kelas IV Sekolah Dasar. Jenis penelitian ini berupa Quasi Experimental Design. Sampel penelitian ini yaitu kelas IV A dan kelas IV B SDN Cikole Kota Sukabumi. Pengumpulan data yang dilakukan berupa metode tes yang terdiri dari pretest dan posttest. Pembelajaran pada kelas eksperimen dilaksanakan dengan menggunakan model pembelajaran VAK sedangkan pembelajaran pada kelas kontrol menggunakan model pembelajaran langsung. Pembelajaran dilaksanakan sebanyak tiga kali pertemuan, baik pada kelas eskperimen maupun kelas kontrol dengan materi yang sama, yaitu bangun datar. Hasil perhitungan awal menunjukkan bahwa kelas eksperimen dan kelas kontrol memiliki kemampuan awal yang sama. Adapun hasil perhitungan akhir menunjukkan bahwa siswa kelas eksperimen memiliki rata-rata hasil belajar lebih tinggi dibandingkan dengan kelas kontrol. Rata-rata hasil akhir kelas eksperimen sebesar 78,95 sedangkan kelas kontrol sebesar 54,74. Adapun hasil pengujian dari Uji $\mathrm{T}$ Dua Sampel Independen menunjukkan nilai sig. $=0,000$. Nilai sig. $>$ taraf signifikansi uji, yaitu 0,05 . Artinya terdapat perbedaan hasil yang signifikan antara kelas eksperimen dan kelas kontrol. Berdasarkan hasil penelitian tersebut dapat disimpulkan bahwa model pembelajaran VAK berpengaruh positif terhadap kemampuan berpikir kritis matematika siswa kelas IV SD pada materi bangun datar.
\end{abstract}

Kata Kunci. Kemampuan Berpikir Kritis, Model Pembelajaran VAK, Bangun Datar

Abstract. The purpose of this research was to know the effect of the VAK learning model towards the fourth grade student's math critical thinking skills on two-dimentional shapes. The type of this research is Quasi Experimental Design. The samples of this research were students from the fourth grade, class A and B, Cikole Elementary School, Sukabumi City. There were two test methods for collecting the data, which was named pretest and posttest. The learning system on experiment class used the VAK learning model, while on the control class was using direct learning model. Learning was done three times in both classes and all was about the two-dimentional shapes. The results of preliminary calculations indicate that

Caruban : Jurnal Ilmiah Pendidikan Dasar 2(2), 102-114, Juli 2019

p-ISSN 2615-1391, e-ISSN 2620-3219 @Prodi PGSD Universitas Swadaya Gunung Jati 


\section{Rariban}

the experimental class and control class have the same initial abilities. As for the final calculation results of the study indicated that the students from the experiment class had higher average learning outcomes than the control class. The average final score of the experiment class was 78,95, whilst 54,74 from the control class. As for the test results of $T$ Test Two Independent Samples indicated sig. $=0,000$. Sig. value smaller significance level of test, that was 0,05. Meaning, there was a significant difference in results between the experiment class and control class. Based on the results of this study can be concluded that the VAK learning model has a positive effect towards the fourth grade student's math critical thinking skills on two-dimentional shapes.

Keywords. Critical Thinking Skills, VAK Learning Model, Two-Dimentional Shapes

\section{Pendahuluan}

Matematika merupakan disiplin ilmu yang berhubungan dengan pola, bentuk, struktur dan penalaran. Melalui matematika diharapkan mampu membentuk manusia yang cerdas, berkualitas serta memberi perubahan positif untuk mencapai tujuan pendidikan dan pembelajaran yang dalam kegiatannya selalu diiringi dengan proses interaksi antar individu atau disebut dengan interaksi edukatif (Riyani, Salimi, \& Marli, 2017: 1). Matematika memiliki peranan penting dalam dunia pendidikan dan dalam menghadapi masalah. Walaupun tidak semua permasalahan termasuk permasalahan matematis, namun matematika berperan penting dalam menjawab permasalahan keseharian. Sesuai dengan pendapat Skemp (dalam Sholihah \& Mahmudi, 2015: 176) bahwa matematika juga merupakan teknik yang bermanfaat dan bertujuan umum untuk memenuhi kebutuhan lain.

Mengingat pentingnya matematika dalam kehidupan sehari-hari, maka matematika menjadi mata pelajaran yang diberikan kepada semua jenjang yang dimulai sejak pendidikan dasar. Hal ini bertujuan agar dapat membekali siswa dalam pemahaman konsep, memakai penalaran pada pola dan sifat, melakukan manipulasi matematika, pemecahan masalah, mengemukakan gagasan, memiliki sikap menghargai dalam penggunaan ilmu matematika dalam kehidupan sehari-hari (Depdiknas, 2006: 346). Matematika juga berperan dalam membentuk dan mengembangkan kemampuan berpikir nalar, logis, sistematis dan kritis (Sulistiani \& Masrukan, 2016: 606). Sedangkan Depdiknas (2006: 16) menyatakan bahwa kemampuan berpikir kritis, logis dan kreatif menjadi salah satu standar kompetensi lulusan mata pelajaran matematika SD/MI.

Matematika dalam proses pembelajarannya memerlukan kemampuan yang tinggi. Terkait dengan aspek pada pembelajaran yang setiap kegiatannya memerlukan kemampuan yang melibatkan aktivitas mental

Caruban : Jurnal Ilmiah Pendidikan Dasar 2(2), 102-114, Juli 2019

p-ISSN 2615-1391, e-ISSN 2620-3219 @Prodi PGSD Universitas Swadaya Gunung Jati 
yang dilakukan siswa dalam merumuskan dan menyelesaikan suatu permasalahan, membuat keputusan yang rasional serta menarik kesimpulan yang tepat sesuai dengan yang diyakini dalam bidang matematika. Kemampuan yang tinggi dalam diri siswa tercermin dalam kemampuan berpkir kritis.

Kemampuan berpikir kritis siswa Indonesia masih rendah. TIMMS tahun 2015 menunjukkan bahwa Indonesia berada di peringkat 45 dari 50 negara. Hal ini salah satunya dipengaruhi oleh pola pengarajarannya yang bersifat kaku (Prahara, 2017). Pelaksanaan pembelajaran matematika di Sekolah Dasar perlu mendorong siswa agar memunculkan ide baru. Tugas guru adalah mengarahkan siswa untuk membantu proses berpikir. Peran guru dalam mengembangkan kemampuan berpikir kritis adalah membangun kemampuan siswa menarik kesimpulan, menganalisis, mensintesis dan mengevaluasi.

Sesuai dengan salah satu kompetensi dalam Kurikulum 2013 yaitu mengembangkan kreativitas, rasa ingin tahu, kemampuan merumuskan pertayaan untuk membentuk pikiran kritis yang perlu untuk hidup cerdas dan belajar sepanjang hayat (Rasiman, 201: 1). Selain itu, sesuai dengan tujuan diberlakukannya Kurikulum 2013 di Indonesia, diantaranya adalah mengembangkan kemampuan berpikir tingkat tinggi, salah satunya adalah berpikir kritis (Azizah, Sulianto \& Cintang, 2018: 63). Dengan demikian, siswa perlu dibekali dengan kemampuan-kemampuan untuk mencapai tujuan Krikulum 2013 tersebut dengan kemampuan berpikir kritis.

Siswa memiliki kemampuan berpikir yang berbeda dalam menyerap, menanggapi serta menguasai pembelajaran yang diberikan oleh guru karena setiap siswa mempunyai gaya belajar yang berbeda dalam belajar. Menurut Bobbi Deporter dan Mike Hernacki (dalam Rahayu \& Istiani, 2017: 132) modalitasnya, gaya belajar dapat dibedakan menjadi tiga, yaitu gaya belajar visual, auditori dan kinestetik. Maka dari itu siswa memerlukan perlakuan yang berbeda sesuai tingkat kemampuan berpikir yang dimilikinya, yakni dengan melakukan variasi dalam proses pembelajaran agar proses pembelajaran menjadi aktif dan berpusat pada siswa. Banyak yang dapat dilakukan agar siswa memiliki kemampuan berpikir kritis yang baik, yaitu dengan melakukan variasi pembelajaran menggunakan model pembelajaran yang tepat.

Terdapat berbagai macam model pembelajaran salah satunya adalah VAK. Model pembelajaran VAK termasuk model pembelajaran kooperatif yang memiliki kelebihan dan kelemahan. Salah satu kelebihannya adalah dapat membuat pembelajaran menjadi lebih efektif karena 
mengkombinasikan ketiga gaya belajar, yaitu Visual, Auditory dan Kinesthetic serta memberikan pengalaman langsung kepada siswa. Siswa Sekolah Dasar pada umumnya lebih mampu menerima materi pembelajaran yang melibatkan penglihatan, pendengaran dan gerak tubuh. Dengan demikian siswa lebih memaknai proses pembelajaran dan dapat mengeksplorasi kemampuan berpikir kritisnya dalam pembelajaran matematika. Karakteristik dari siswa Sekolah Dasar tersebut sesuai dengan model pembelajaran VAK.

Model pembelajaran VAK merupakan solusi yang sangat cerdas dimana ketiga kecenderungan gaya belajar seseorang digabungkan menjadi satu sehingga dapat meminimalisir terjadinya kesulitan belajar siswa yang juga disebabkan oleh gaya belajar yang kurang sesuai pada proses pembelajaran berlangsung (Rahayu, Riyana \& Silvana, 2017: 95). Karena proses berpikir kritis siswa dalam proses pembelajaran dipengaruhi oleh salah satu faktor dalam diri, yaitu gaya belajar. Artinya pada proses berpikir siswa terdapat hubungan terhadap gaya belajar yang biasa digunakan dalam proses pembelajaran matematika (Marfuah, Mardiyana \& Subanti, 2016: 624). Sejalan dengan penelitian terdahulu yang dilakukan oleh Amir (2015) dalam penelitiannya bahwa proses berpikir kritis dalam memecahkan masalah berbentuk soal cerita matematika berdasarkan gaya belajar (Visual-AuditoryKinesthetic) lebih efektif dalam proses pembelajaran. Hal serupa diungkap oleh Wibowo, Sarengat \& Astuti (2017) yang menjelaskan bahwa model pembelajaran VAK berpengaruh posif terhadap hasil belajar matematika di Sekolah Dasar. Sehingga berdampak pada rata-rata hasil belajar siswa dalam pembelajaran matematika dengan model pembelajaran VAK yang mengkobinasikan tiga gaya belajar dalam waktu yang bersamaan lebih tinggi dibandingkan dengan siswa yang tidak menggunakan model pembelajaran VAK dalam pembelajaran matematika.

Berdasarkan permasalahan tersebut, peneliti termotivasi untuk menggunakan model pembelajaran VAK yang diharapkan dapat berpengaruh terhadap kemampuan berpikir kritis siswa dalam pembelajaran matematika. Sedangkan rumusan masalahnya adalah apakah model pembelajaran VAK berpengaruh terhadap kemampuan berpikir kritis siswa di kelas tinggi Sekolah Dasar.

\section{Metode Penelitian}

Jenis penelitian yang digunakan dalam penelitian ini adalah jenis penelitian kuasi eksperimen atau Quasi Experimental Design. Metode kuasi eksperimen adalah metode yang memiliki kelompok kontrol, tetapi tidak dapat berfungsi sepenuhnya untuk mengontrol variabel-variabel luar yang 
mempengaruhi pelaksanaan eksperimen (Sugiyono, 2015: 114). Penelitian dilakukan dengan membagi kelompok yang diteliti menjadi dua kelompok, yaitu kelompok eksperimen yang mendapatkan perlakuan dengan menggunakan model pembelajaran VAK dalam proses pembelajaran matematika dan kelompok kedua adalah kelompok kontrol tidak menggunakan model pembelajaran VAK dalam proses pembelajaran matematika. Adapun desain penelitian eksperimen yang digunakan dalam penelitian ini adalah Nonequivalent Control Group Design. Pada desain ini kelompok eksperimen maupun kelompok kontrol tidak dipilih secara random (Sugiyono, 2015: 116).

Populasi penelitian ini yaitu seluruh siswa kelas IV SDN Cikole Kota Sukabumi. Sampel yang digunakan pada penelitian ini yaitu sampling jenuh. Menurut Sugiyono (2015: 124) sampling jenuh adalah sampel yang digunakan dimana seluruh populasi digunakan sebagai sampel penelitian. Sampel pada penelitian ini terdiri dari 38 orang siswa yaitu 19 orang siswa dari kelas IV A dan 19 orang siswa dari kelas IV B.

Teknik pengumpulan data yang digunakan dalam penelitian ini adalah teknik tes. Tes yang digunakan dalam penelitian ini berupa Pretest (sebelum diberikan perlakuan) dan Posttest (setelah diberikan perlakuan). Soal diujicobakan dengan melakukan uji validitas, reliabilitas, tingkat kesukaran, dan daya pembeda. Hal tersebut dilakukan untuk mengetahui adanya pengaruh model pembelajaran VAK terhadap kemampuan berpikir kritis siswa dalam pembelajaran matematika.

Setelah seluruh data terkumpul, maka dilakukan teknik analisis data dengan tujuan mengolah data tersebut untuk menjawab rumusan masalah. Teknik analisis data dalam penelitian ini meliputi uji prasyarat analisis, analisis data pretest dan analisis data posttest yang diuji menggunakan bantuan aplikasi SPSS 16 dengan taraf signifikansi 0,05, yaitu uji normalitas, uji homogenitas, uji t dua sampel independen serta uji paired sample t test.

\section{Hasil Dan Pembahasan}

Penelitian ini dilaksanakan pada semester genap tahun ajaran 2018/2019 di SDN Cikole yang terletak di Jl. Rumah Sakit R. Syamsudin, S. H. Belakang No. 3 Kota Sukabumi, Jawa Barat. Penelitian ini dimulai pada tanggal 27 Februari sampai dengan 6 April 2019. Sampel yang digunakan adalah sampling jenuh karena seluruh populasi dalam penelitian ini dijadikan sebagai sampel penelitian. Sampel berjumlah dua kelas, yaitu kelas IV A sebagai kelas eksperimen yang berjumlah 19 orang dan kelas IV B sebagai kelas kontrol yang berjumlah 19 orang. Pada proses pembelajarannya, kedua kelas tersebut mendapatkan perlakuan yang 
berbeda. Kelas eksperimen dilakukan pada kelas IV A dengan melaksanakan pembelajaran pada materi bangun datar dengan menggunakan model pembelajaran VAK, sedangkan kelas kontrol dilakukan pada kelas IV B dengan melaksanakan pembelajaran tanpa menggunakan model pembelajaran VAK.

Data nilai pretest kemudian dihitung menggunakan uji prasyarat, yaitu dengan menggunakan uji normalitas dan uji homogenitas. Uji normalitas digunakan untuk mengetahui apakah data berasal dari populasi berdistribusi normal atau tidak. Sedangkan uji homogenitas digunakan untuk mengetahui apakah varians data dari kedua sampel bervarians homogen atau tidak. Hasil data pretest dari kelas eksperimen dan kelas kontrol diuji menggunakan uji T dua sampel independent untuk mengetahui apakah kelas eksperimen dan kelas kontrol memiliki kemampuan awal yang sama sebelum dilaksanakan penelitian. Uji $\mathrm{T}$ dua sampel independen dilakukan dengan menggunakan bantuan aplikasi SPSS 16 dengan taraf signifikansi 0,05.

Tabel 1. Hasil Uji T Dua Sampel Independen Kemampuan Awal Siswa

\begin{tabular}{lccc}
\hline \multicolumn{1}{c}{ Sampel } & Rata-Rata & Nilai sig. (2-tailed) & Keputusan \\
\hline $\begin{array}{l}\text { Kelas Eksperimen } \\
\text { Kelas Kontrol }\end{array}$ & 50.26 & 0.799 & Ho Diterima \\
\hline
\end{tabular}

Berdasarkan Tabel 1. dapat dilihat bahwa hasil pengujian dari uji $\mathrm{T}$ dua sampel independent didapatkan nilai sig. 0,585 dan 0,584. Karena nilai sig. > 0,05 maka $\mathrm{H}_{0}$ diterima dan $\mathrm{H}_{1}$ ditolak. Dapat disimpulkan bahwa kelas ekperimen dan kelas kontrol memiliki kemampuan awal yang sama.

Sama halnya dengan data nilai posttest kemudian dihitung menggunakan uji prasyarat, yaitu dengan menggunakan uji normalitas dan uji homogenitas. Hasil pengujian normalitas untuk kelas eksperimen menggunakan uji Kolmogorov-Smirnov diperoleh nilai sig. 0,200 dan dengan uji Saphiro-Wilk diperoleh nilai sig. 0,085. Karena kedua nilai sig. > 0,05 maka $\mathrm{H}_{0}$ diterima dan dapat disimpulkan bahwa data hasil posttest kelas eksperimen berasal dari populasi yang berdistribusi normal. Sedangkan pada kelas kontrol, hasil pengujian normalitas menggunakan uji Kolmogorov-Smirnov diperoleh nilai sig. 0,200 dan dengan uji Saphiro-Wilk diperoleh nilai sig. 0,079. Karena kedua nilai sig. > 0,05 maka $\mathrm{H}_{0}$ diterima dan dapat disimpulkan bahwa data hasil posttest kelas kontrol berasal dari populasi yang berdistribusi normal. Hasil pengujian homogenitas data kemampuan awal siswa (pretest) diperoleh nilai sig. $=0,099$. Karena kedua nilai sig. $>0,05$ maka $\mathrm{H}_{0}$ diterima. Sehingga dapat disimpulkan bahwa data hasil kemampuan akhir siswa (posttest) kelas eksperimen dan kelas kontrol berasal dari populasi yang bervarians homogen. Untuk mengetahui 
perbedaan hasil sebelum dan sesudah diberikan perlakuan. Maka di uji menggunakan Uji Paired-Samples T Test. Hal tersebut dilakukan pada hasil posttest dan hasil pretest kelas eksperimen dan kelas kontrol.

Tabel 2. Hasil Uji Paired Sample T Test

\begin{tabular}{lcccc}
\hline \multicolumn{1}{c}{ Sampel } & Rata-rata Pretest & Rata-rata Post test & Nilai Sig. (2-tailed) & Keputusan \\
\hline Kelas Eksperimen & 50,26 & 78,95 & 0,000 & Ho ditolak \\
Kelas Kontrol & 48,68 & 54,74 & 0,132 & Ho diterima \\
\hline
\end{tabular}

Berdasarkan Tabel 2. di atas dapat dilihat bahwa hasil pengujian dari uji Paired Sample T Test didapatkan nilai sig. $=0,000$ untuk kelas eksperimen. Karena nilai sig. $<0,05$ maka $\mathrm{H}_{0}$ ditolak dan $\mathrm{H}_{1}$ diterima. Sedangkan untuk kelas kontrol diperoleh nilai sig. 0,132. Karena nilai sig. $>0,05$ maka $\mathrm{H}_{0}$ diterima dan $\mathrm{H}_{1}$ ditolak. Setelah dilakukan pengujian menggunakan uji Paired Sample T Test dapat dilihat bahwa terdapat perbedaan hasil pretest dan hasil posttest untuk kelas eksperimen, sedangkan kelas kontrol tidak terdapat perbedaan antara pretest dan posttest.

Untuk menjawab rumusan masalah dalam penelitian ini yaitu dengan uji hipotesis menggunakan uji $\mathrm{T}$ dua sampel independen. Uji T dua sampel independen dilakukan dengan menggunakan SPSS 16 dengan taraf signifikansi 0,05. Kriteria uji yaitu $\mathrm{H}_{0}$ ditolak dan $\mathrm{H}_{1}$ diterima jika nilai sig. < 0,05 . Adapun hasil dari pengujian uji $\mathrm{T}$ dua sampel independen dapat dilihat pada Tabel 3. sebagai berikut.

Tabel 3. Hasil Uji Hipotesis

\begin{tabular}{lccc}
\hline \multicolumn{1}{c}{ Sampel } & Rata-rata & Nilai sig. (2-tailed) & Keputusan \\
\hline Kelas Eksperimen & 78,95 & 0,000 & Ho ditolak \\
Kelas Kontrol & 54,74 & 0,000 \\
\hline
\end{tabular}

Berdasarkan Tabel 3. dapat dilihat bahwa hasil uji hipotesis dengan menggunakan uji $\mathrm{T}$ dua sampel independen didapatkan nilai sig. $=0,000$. Dengan demikian dapat disimpulkan bahwa $\mathrm{H}_{0}$ ditolak dan $\mathrm{H}_{1}$ diterima karena nilai sig. lebih kecil dari taraf signifikansi uji $(0,05)$. Artinya terdapat perbedaan yang signifikansi antara kelas eksperimen dan kelas kontrol.

Berdasarkan hasil posttest diperoleh rata-rata nilai kelas eksperimen lebih besar dari rata-rata nilai kelas kontrol. Siswa yang belajar dengan menggunakan model pembelajaran VAK memperoleh hasil rata-rata posttest sebesar 78,95 sedangkan siswa yang belajar tanpa menggunakan model pembelajaran VAK atau menggunakan pembelajaran langsung memeproleh nilai rata-rata sebesar 54,74. Maka dapat disimpulkan bahwa terdapat perbedaan yang signifikan antara hasil posttest kelas eksperimen dan hasil posttest kelas kontrol. Siswa yang belajar dengan menggunakan model pembelajaran VAK mengalami peningkatan dan memiliki rata-rata yang lebih tinggi daripada siswa yang belajar dengan menggunakan pembelajaran

Caruban : Jurnal Ilmiah Pendidikan Dasar 2(2), 102-114, Juli 2019

p-ISSN 2615-1391, e-ISSN 2620-3219 @Prodi PGSD Universitas Swadaya Gunung Jati 
langsung. Hal ini sejalan dengan penelitian yang telah dilakukan oleh Rifai (2018) bahwa rata-rata hasil belajar matematika yang menggunakan model pembelajaran VAK lebih tinggi dari rata-rata hasil belajar matematika yang menggunakan model pembelajaran langsung. Hal ini sejalan dengan penelitian yang telah dilakukan oleh Rifai (2018) bahwa rata-rata hasil belajar matematika yang menggunakan model pembelajaran VAK lebih tinggi dari rata-rata hasil belajar matematika yang menggunakan model pembelajaran langsung.

Terdapat beberapa faktor penyebabnya, diantaranya adalah pada kelas eksperimen siswa diberikan perlakuan, yaitu dengan menggunakan model pembelajaran VAK dimana siswa dilibatkan secara utuh dalam kegiatan yang dapat mengoptimalkan ketiga gaya belajar, yaitu visual, auditory dan kinesthetic. Sesuai dengan kelebihan dari model pembelajaran VAK menurut Shoimin (2014: 228) yang menyatakan bahwa pembelajaran akan berlangsung lebih efektif dan efisien karena mengombinasikan ketiga gaya belajar. Menurut Herdian (dalam Shoimin, 2014: 226) menjelaskan bahwa:

Model pembelajaran VAK merupakan suatu model pembelajaran yang menganggap pembelajaran akan efektif dengan memperhatikan ketiga hal tersebut (visual, auditory dan kinesthetic) dan dapat diartikan bahwa pembelajaran dilaksanakan dengan memanfaatkan potensi siswa yang telah dimilikinya dengan melatih dan mengembangkannya.

Oleh karena itu, guru harus mampu memahami karakteristik masingmasing siswa dan gaya belajarnya masing-masing agar potensi yang mereka miliki dapat berkembang dengan baik. Salah satu karakteristik yang perlu diperhatikan dalam merancang proses pembelajaran adalah gaya belajar (Alfin, 2015: 192). Karakteristik siswa mampu membantu mengoptimalkan kemampuan yang dimiliki dalam proses pembelajaran. Kemampuan yang diukur dalam penelitian ini adalah kemampuan berpikir kritis siswa dalam pembelajaran matematika. Kemampuan berpikir kritis ini dioptimalkan melalui gaya belajar dan dari gaya belajar tersebut berkembang menjadi model pembelajaran VAK.

Model pembelajaran VAK yang digunakan dalam proses pembelajaran di kelas eksperimen pada penelitian ini menggunakan media pembelajaran sebagai alat pendukung pembelajaran dalam mengaplikasikan kegiatan visual dan kinesthetic yang disesuaikan dengan materi yang sedang diajarkan. Karena menurut teori Piaget (dalam Soesilawati, 2011: 29) menyatakan bahwa tahap perkembangan kognisi anak pada usia 7-12 merupakan tahap operasi konkret. Artinya, media pembelajaran sebagai benda konkret

Caruban : Jurnal Ilmiah Pendidikan Dasar 2(2), 102-114, Juli 2019

p-ISSN 2615-1391, e-ISSN 2620-3219 @Prodi PGSD Universitas Swadaya Gunung Jati 
mampu mendukung proses pembelajaran menjadi lebih efektif dan materi yang diajarkan dapat dipahami oleh siswa.

Selain itu, pada kelas eksperimen proses pembelajaran siswa dibentuk menjadi beberapa kelompok secara heterogen. Menurut Artz dan Newman (dalam Warmansyah, 2016: 104) bahwa dalam pembelajaran berkelompok siswa bekerjasama dalam satu tim untuk mengatasi masalah dan mencapai tujuan bersama. Dalam kelompok ini siswa melakukan kegiatan diskusi dan mengamati benda-benda di sekitar kelas yang relevan dengan materi yang diajarkan. Adapun dalam mengaplikasikan kegiatan auditory, peneliti membuat lagu berkaitan dengan materi yang diajarkan, dengan tujuan agar memudahkan siswa dalam memahami materi. Karena menurut Huda (2013: 288) bahwa seorang siswa auditoris memiliki ciri-ciri perhatiannya mudah terpecah, berbicara dengan pola berirama, belajar dengan cara mendengarkan atau berdialog secara internal dan eksternal. Adapun dalam mengaplikasikan kegiatan kinesthetic, siswa diajak untuk melakukan kegiatan seperti melipat, menempel, menggunting, mengukur menggunakan penggaris, busur derajat serta berpindah tempat dalam pembagian kelompok. Hal ini sesuai dengan pendapat Huda (2013: 288) bahwa siswa yang cenderung kinestetik memiliki ciri-ciri banyak gerak, belajar sambil bekerja serta mengingat sambil berjalan dan melihat.

Adanya Lembar Kerja Siswa (LKS) juga membantu siswa dalam memahami materi dan berpikir secara kritis dalam menjawab soal bangun datar dengan berdiskusi kelompok. Sesuai dengan pendapat Prastowo (dalam Sriyono, Yamtiningsih dan Wibowo, 2018: 308) bahwa LKS berfungsi mengaktifkan peserta didik dan mempermudah peserta didik dalam memahami materi. LKS dianggap praktis untuk mengoptimalkan berpikir kritis siswa dalam pembelajaran matematika (Sriyono, Yamtiningsih dan Wibowo, 2018: 312). Selain itu, dengan berdiskusi kelompok dapat memudahkan dalam memahami materi juga melatih dalam kemampuan sosial, kemampuan untuk saling bekerjasama, memahami, berbagi informasi, membantu antar teman kelompok dan bertanggung jawab mencapai tujuan bersama. Hal tersebut sesuai dengan pendapat Ardika, Rosidin \& Wahyudi (2016: 116) yang menyatakan bahwa 'digunakannya LKS dapat menciptakan situasi pembelajaran yang memungkinkan siswa lebih banyak mengkontruksi pengetahuannya secara personal atau sosial'. Pada saat siswa sedang melakukan kegiatan diskusi kelompok ini, maka mereka mengoptimalkan ketiga gaya belajar (visual, auditory dan kinesthetic) secara bersamaan. Kemudian dalam model pembelajaran VAK juga terdapat hal yang dapat memotivasi anak dalam proses pembelajaran dimana pada tahap

Caruban : Jurnal Ilmiah Pendidikan Dasar 2(2), 102-114, Juli 2019

p-ISSN 2615-1391, e-ISSN 2620-3219 @Prodi PGSD Universitas Swadaya Gunung Jati 
penyampaian hasil siswa akan diberikan sebuah penghargaan berupa pujian dan nilai tambah dalam kelompok sesuai dengan tingkat pencapaiannya. Sehingga siswa terus termotivasi dalam belajar dan berdampak pada terus meningkatnya skor yang diperoleh setiap pertemuannya.

Hal tersebut berbeda dengan kelas kontrol yang belajar dengan menggunakan pembelajaran langsung. Pada proses pelaksanaan pembelajarannya siswa hanya melakukan kegiatan diskusi dengan teman sebangkunya saja bahkan ada beberapa yang melakukannya secara mandiri dan pembelajaran lebih berpusat pada guru sehingga siswa terlihat pasif saat kegiatan belajar mengajar berlangsung. Sebagaimana yang dikatakan oleh Nasution (dalam Zulyadaini, 2016: 156) bahwa dengan pembelajaran langsung atau dengan metode konvensional siswa kebanyakan bersikap pasif karena harus mendengarkan uraian guru dan belajar menurut kecepatan guru, siswa hanya menerima, mencatat dan menghafal materi. Siswa tidak diberikan LKS dan hanya diberikan latihan soal untuk melatih kemampuannya dalam berpikir kritis matematika materi bangun datar. Sehingga siswa merasa jenuh dan bosan dengan pembelajaran yang monoton, jenuh, membosankan dan akhirnya minat belajar semakin menurun.

Berdasarkan uraian di atas, telah diperoleh data bahwa siswa yang belajar dengan menggunakan model pembelajaran VAK memiliki hasil belajar yang lebih tinggi dibandingkan dengan hasil belajar siswa yang belajar dengan menggunakan pembelajaran langsung. Maka, dapat disimpulkan bahwa model pembelajaran VAK dapat berpengaruh positif terhadap kemampuan berpikir kritis siswa Sekolah Dasar di kelas tinggi pada mata pelajaran matematika materi bangun datar. Hasil penelitian ini menguatkan pernyataan dari Amir (2015) dalam penelitiannya bahwa proses berpikir kritis dalam memecahkan masalah berbentuk soal cerita dalam pembelajaran matematika berdasarkan gaya belajar (Visual-AuditoryKinesthetic) berdampak positif dan efektif jika diterapkan dalam proses pembelajaran. Adapun menurut Wibowo, Sarengat \& Astuti (2017) dalam penelitiannya bahwa model pembelajaran VAK berpengaruh signifikan dan positif terhadap hasil belajar matematika siswa.

\section{Simpulan Dan Rekomendasi}

Terdapat perbedaan hasil akhir yang signifikan antara kelas eksperimen dengan kelas kontrol. Siswa yang belajar dengan model pembelajaran VAK memiliki hasil belajar yang lebih tinggi dibandingkan dengan siswa yang belajar dengan pembelajaran langsung. Dibuktikan dengan perolehan hasil rata-rata posttest kelas eksperimen, yaitu sebesar 
78,95 sedangkan perolehan hasil rata-rata posttest kelas kontrol, yaitu 54,74. Adapun berdasarkan hasil analisis Uji T Dua Sampel Independen diperoleh nilai sig. < dari taraf signifikansi 0,05 yaitu nilai sig. $=0,000$ sehingga $\mathrm{H}_{0}$ ditolak dan $\mathrm{H}_{1}$ diterima, artinya terdapat perbedaan yang siginifikan dari hasil posttest kelas eksperimen dan kelas kontrol. Sejalan dengan penelitian Amir (2015) bahwa proses berpikir kritis dalam memecahkan masalah berbentuk soal cerita dalam pembelajaran matematika berdasarkan gaya belajar (Visual-Auditory-Kinesthetic) berdampak positif dan efektif jika diterapkan dalam proses pembelajaran. Maka, dapat disimpulkan bahwa model pembelajaran VAK memberikan pengaruh terhadap kemampuan berpikir kritis siswa pada materi bangun datar di kelas IV SDN Cikole Kota Sukabumi.

Adapun rekomendasi yang diberikan dalam penelitian ini adalah model pembelajaran VAK memerlukan waktu yang cukup lama dalam pelaksanaannya pada proses pembelajaran, sehingga guru harus mampu mengoptimalkan waktu yang ada dengan ketiga gaya belajar siswa yaitu visual, auditory dan kinesthetic. Kemudian dibantu dengan penggunaan alat pendukung pembelajaran atau media pembelajaran yang relevan dengan materi yang sedang diajarkan agar pembelajaran lebih efektif dan materi yang diajarkan mudah dipahami oleh siswa. Guru dapat menerapkan atau mengembangkan model pembelajaran VAK dalam proses pembelajaran matematika di Sekolah Dasar sebagai salah satu alternatif pilihan dalam meningkatkan kompetensi belajar siswa serta untuk menciptakan proses pembelajaran yang aktif, partisipatif, menyenangkan dan relevan dengan kebutuhan siswa di Sekolah Dasar sesuai dengan tingkatan kelasnya.

\section{Daftar Pustaka}

Alfin, J. (2015). Analisis Karakteristik Siswa Pada Tingkat Sekolah Dasar. Prosiding Halaqah Nasional \& Seminar Internasional Pendidikan Islam. Surabaya: UIN Sunan Ampel.

Amir, M. F. (2015). Proses Berpikir Kritis Siswa Sekolah Dasar Dalam Memecahkan Masalah Berbentuk Soal Cerita Matematika Berdasarkan Gaya Belajar (Visual-Auditory-Kinesthetic). Jurnal Math Educator Nusantara. 1(2). Universitas Muhammdiyah Sidoarjo.

Ardika, P., Rosidin, U., \& Wahyudi, I. (2016). Pengaruh LKS PjBL Terhadap Hasil Belajar Siswa SMP Pada Materi Suhu dan Perubahannya. Jurnal Pembelajaran Fisika FKIP Universitas Lampung, 4(3), 116.

Azizah, M., Sulianto, J., \& Cintang, N. (2018). Analisis Keterampilan Berpikir Kritis Siswa Sekolah Dasar Pada Pembelajaran Matematika Matematika

Caruban : Jurnal Ilmiah Pendidikan Dasar 2(2), 102-114, Juli 2019

p-ISSN 2615-1391, e-ISSN 2620-3219 @Prodi PGSD Universitas Swadaya Gunung Jati 
Kurikulum 2013. Jurnal Penelitian Pendidikan. 35 (1), 63.

Depdiknas. (2006). Peraturan Menteri Pendidikan Nasional Republik Indonesia Nomor 22 Tahun 2006 Tentang Standar Isi Untuk Satuan Pendidikan Dasar Dan Menengah. Jakarta: Depdiknas.

Depdiknas. (2006). Peraturan Menteri Pendidikan Nasional Republik Indonesia Nomor 23 Tahun 2006 Tentang Standar Kompetensi Lulusan Untuk Satuan Pendidikan Dasar Dan Menengah. Jakarta: Depdiknas. Jakarta: Depdiknas.

Huda, M. (2013). Model-Model Pengajaran dan Pembelajaran. Yogyakarta: Pustaka Belajar.

Marfuah, I., Mardiyana., \& Subanti, S. (2016). Proses Berpikir Kritis Dalam Memecahkan Masalah Sistem Persamaan Linier Dua Variabel Ditinjau Dari Gaya Belajar (Visual, Auditori, Kinestetik) Kelas IX B SMP Negeri 2 Surakarta Tahun Pelajaran 2015/2016. Tesis Magister pada FKIP Universitas Sebelas Maret. Surakarta: tidak diterbitkan.

Prahara, H. (2017). Pada 2020, Tak Ada Lagi Pelajaran Matematika di Negara Ini!

Tersedia: https:/edukasi.kompas.com?read/201709/19/13445611/pada2020-tak-ada-lagi-pelajaran-matematika-di-negara-ini. [Desember 2018]

Rahayu, S., \& Istiani, A. (2017). Pembelajaran Matematika Melalui Pendekatan Konteks Dengan Gaya Belajar Belajar VAK (Visual-AuditoryKinesthetic). Jurnal Edumath. 3 (2), 132.

Rahayu, M. R., Riyana, C., \& Silvana, H. (2017). Efektivitas Penerapan Model Pembelajaran VAK Terhadap Peningkatan Kemampuan Berpikir Kreatif Siswa Pada Mata Pelajaran Bahasa Indonesia. Edutechologia: Jurnal Universitas Pendidikan Indonesia. 3 (2), 95.

Rasiman. (2013). Meningkatkan Kemampuan Berpikir Kritis Melalui Pembelajaran Matematika Dengan Pendekatan Matematika Realistik. Aksioma: Jurnal Matematika dan Pendidikan Matematika. 4(2), 1.

Riyani, E. E. R., Salimi, A., \& Marli, S. (2017). Peningkatan Interaksi Edukatif Dan Hasil Belajar Menggunakan Metode Role Playing. Jurnal FKIP Universitas Tanjungpura. 6(3), 1.

Rifai, M. (2018). Pengaruh Model Pembelajaran Visual Auditory Kinesthetic (VAK) Terhadap Hasil Belajar Matematika Siswa Kelas IV SD Negeri 01 Binakarya Baru. Skripsi Sarjana pada FKIP Universitas Lampung. Bandar Lampung: tidak diterbitkan.

Shoimin, Aris. (2014). 68 Model Pembelajaran Inovatif dalam Kurikulum 2013. Yogyakarta: Ar-Ruzz Media.

Sholilah, D. A., \& Mahmudi, A. (2015). Keefektifan Experiental Learning Pembelajaran Matematika MTs Materi Bangun Ruang Sisi Datar. Jurnal Riset Pendidikan Matematika. 2 (2), 176.

Caruban : Jurnal Ilmiah Pendidikan Dasar 2(2), 102-114, Juli 2019 p-ISSN 2615-1391, e-ISSN 2620-3219 @Prodi PGSD Universitas Swadaya Gunung Jati 
Soesilowati. (2011). Perkalian Itu Asyik dan Menyenangkan. Jakarta: PT Gramedia Pustaka Utama.

Sriyono., Yamtiningsih., \& Wibowo, T. (2018). Pengembangan LKS Matematika Untuk Mengoptimalkan Berpikir Kritis Siswa. Prosiding Seminar Nasional Matematika dan Pendidikan Matematika, "Integrasi Budaya, Psikologi dan Teknologi dalam Membangun Pendidikan Karakter Melalui Matematika dan Pembelajarannya". Purworejo: Universitas Muhammadiyah Purworejo. 208-312.

Sugiyono. (2015). Metode Penelitian Pendidikan. Bandung: Alfabeta.

Sulistiani, E., \& Masrukan. (2016). Pentingnya Berpikir Kritis dalam Pembelajaran Matematika untuk Menghadapi Tantangan MEA. Seminar Nasional Matematika X Universitas Negeri semarang, 2, 606.

Warmansyah, J. (2016). Pengaruh Metode Pembelajaran Kooperatif Dan Motivasi Belajar Terhadap Hasil Belajar Matematika. Jurnal Pendidikan Usia Dini Universitas Negeri Jakarta. 10, 104.

Wibowo, A. T., Sarengat., \& Astuti, N. (2017). Pengaruh Model Pembelajaran

Visual Auditory Kinesthetic Terhadap Hasil Belajar Matematika Siswa SD. Jurnal Pedagogi Universitas Negeri Lampung, 6(4), 1-13.

Zulyadaini. (2016). Perbandingan Hasil Belajar Matematika Model Pembelajaran Kooperatif Tipe Coop-Coop Dengan Konvensional. Jurnal Ilmiah Universitas Batanghari Jambi, 16 (1), 156. 